\title{
Effects of caffeine, tea polyphenol and daidzein on the pharmacokinetics of lansoprazole and its metabolites in rats
}

\author{
Tao Wu1, Ji Wu², Ping Gao³, Daochun Xiang ${ }^{4}$, Dong Liu ${ }^{5}$, Hongping Song1,"
}

${ }^{1}$ Department of Pharmacy, Puai Hospital, Tongji Medical College, Huazhong University of Science and Technology, Wuhan, China, ${ }^{2}$ Department of Medicine, City College, Wuhan University of Science and Technology, Wuhan, China, ${ }^{3}$ Department of Pharmacy, Wuhan Medical Care Center for Women and Children, Wuhan, China, ${ }^{4}$ Department of Pharmacy, Wuhan Central Hospital, Wuhan, China, ${ }^{5}$ Department of Pharmacy, Tongji Hospital, Tongji Medical College, Huazhong University of Science and Technology, Wuhan, China

\begin{abstract}
The aim of this study was to evaluate the effects of caffeine, tea polyphenol and daidzein on the pharmacokinetics of lansoprazole and its metabolites. Rats were intragastrically administered caffeine (30 mg $\cdot \mathrm{kg}^{-1}$, once per day), tea polyphenol (400 $\mathrm{mg} \cdot \mathrm{kg}^{-1}$, once per day) or daidzein $\left(13.5 \mathrm{mg} \cdot \mathrm{kg}^{-1}\right.$, once per day) for 14 days, followed by an intragastric administration of lansoprazole $\left(8 \mathrm{mg} \cdot \mathrm{kg}^{-1}\right)$ on the 15 th day. The plasma concentrations of lansoprazole and its two primary metabolites, 5-hydroxylansoprazole and lansoprazole sulfone, were determined by high-performance liquid chromatography coupled with tandem mass spectrometry (HPLC-MS/MS). Tea polyphenol significantly elevated the Area Under the Curve (AUC) of lansoprazole from $680.29 \pm 285.99$ to $949.76 \pm 155.18 \mu \mathrm{g} / \mathrm{L} . \mathrm{h}$ and reduced that of lansoprazole sulfone from $268.82 \pm 82.37$ to $177.72 \pm 29.73 \mu \mathrm{g} / \mathrm{L}$.h. Daidzein increased the AUC of lansoprazole from $680.29 \pm 285.99$ to $1130.44 \pm 97.6 \mu \mathrm{g} / \mathrm{L}$.h and decreased that of lansoprazole sulfone from $268.82 \pm 82.37$ to $116.23 \pm 40.14 \mu \mathrm{g} / \mathrm{L}$.h. The pharmacokinetics of 5-hydroxylansoprazole remained intact in the presence of tea polyphenol or daidzein. Caffeine did not affect the pharmacokinetics of lansoprazole and its metabolites. The results imply that tea polyphenol and daidzein may inhibit the in vivo metabolism of lansoprazole by suppressing CYP3A.
\end{abstract}

Uniterms: Lansoprazole/pharmacokinetics. Caffeine/effects/lansoprazole pharmacokinetics. Tea polyphenol/effects/lansoprazole pharmacokinetics. Daidzein/effects/lansoprazole pharmacokinetics. 5-hydroxylansoprazole. Lansoprazole sulfone. Hepatic microsomal enzyme/inhibition.

O objetivo deste estudo foi avaliar os efeitos da cafeína, do polifenol do chá e da daidzeína na farmacocinética do lansoprazol e de seus metabólitos. Administraram-se, intragastricamente, aos ratos cafeína (30 mg $\cdot \mathrm{kg}^{-1}$, uma vez ao dia), polifenol do chá $\left(400 \mathrm{mg} \cdot \mathrm{kg}^{-1}\right.$, uma vez ao dia) ou daidzeína (13,5 $\mathrm{mg} \cdot \mathrm{kg}^{-1}$, uma vez ao dia), por 14 dias, seguindo-se a administração de lansoprazol $\left(8 \mathrm{mg} \cdot \mathrm{kg}^{-1}\right)$ no $15^{\circ}$. dia. As concentrações plasmáticas do lansoprazol e de seus dois metabólitos primários, 5-hidroxilansoprazol e sulfona de lansoprazol, foram determinadas por cromatografia líquida de alta eficiência acoplada com espectrometria de massas (CLAE-EM/EM). O polifenol do chá elevou, significativamente, a Área Sob a Curva (ASC) do lansoprazol de 680,29 $\pm 285,99$ para 949,76 $\pm 155,18 \mu \mathrm{g} / \mathrm{L}$.h e reduziu a da sulfona de lansoprazol de 268,82 $\pm 82,37$ para 177,72 $\pm 29,73 \mu \mathrm{g} / \mathrm{L}$.h. A daidzeína aumentou a ASC do lansoprazol de $680,29 \pm 285,99$ para 1130,44 $\pm 97,6 \mu \mathrm{g} / \mathrm{L}$.h e reduziu a da sulfona de lansoprazol de $268,82 \pm 82,37$ para $177,72 \pm 29,73 \mu \mathrm{g} / \mathrm{L}$.h. A farmacocinética do 5 -hidroxilansoprazol permaneceu intacta na presença de polifenol do chá ou daidzeína. A cafeína não afetou a farmacocinética do lansoprazol e de seus metabólitos. Os resultados sugerem que o polifenol do chá e a daidzeína podem inibir o metabolismo in vivo do lansoprazol por supressão da CYP3A.

Unitermos: Lansoprazol/farmacocinética. Cafeína/efeitos/farmacocinética do lansoprazol. Polifenol/efeitos/farmacocinética do lansoprazol. Daidzeína/efeitos/farmacocinética do lansoprazol. 5-Hidroxilansoprazol. Sulfona de lansoprazol. Enzima microssômica hepática/inibição.

\footnotetext{
*Correspondence: Hongping Song. Department of Pharmacy. Puai Hospital, 


\section{INTRODUCTION}

The possible interaction between dietary factors and drugs, which has recently come into focus, is readily observed as cytochrome P450 (CYP450) enzyme inhibition. For instance, grapefruit juice can inhibit the activity of hepatic microsomal enzyme CYP3A4, and betel nut, coconut and garlic exert inhibitory effects on the activity of CYP2E1 (Nowack, 2008; Britto et al., 1991). Taking these foods simultaneously slows the metabolism of the drugs involved, elevates the plasma concentration, and leads to adverse drug reactions.

Lansoprazole, which is a proton pump inhibitor, is typically used to treat peptic ulcers. As a potent antacid, lansoprazole inhibits gastric acid secretion, reinforces the defense of gastric parietal cells and accelerates ulcer healing by suppressing $\mathrm{H}^{+} / \mathrm{K}^{+}$-ATP enzymatic activity. In addition, lansoprazole shows superb performance in eradicating gastric Helicobacter pylori (Inoue et al., 2010). These characteristics have allowed lansoprazole to be widely used in treating gastric acid-related diseases, such as gastric ulcer, gastroesophageal reflux disease and Zollinger-Ellison syndrome (Spencer, Faulds, 1994). Thus, the possible interactions between lansoprazole and other drugs and foods need to be carefully considered. Lansoprazole is metabolized into 5-hydroxylansoprazole and lansoprazole sulfone primarily by CYP2C19 and CYP3A at low and high concentrations, respectively. CYP2C19 is polymorphic, which has significant effects on the pharmacokinetics of lansoprazole and its metabolites. The differences in pharmacokinetics between CYP2C19 extensive metabolizers and poor metabolizers are more significant for lansoprazole sulfone than for 5-hydroxylansoprazole (Zhang et al., 2012). Therefore, any food components metabolized by CYP2C19 or CYP3A, especially those that affect CYPs, may influence the pharmacokinetics of lansoprazole in vivo (Saito et al., 2005).

Dietary factors, such as coffee and tea consumption together with soy products, impact drug absorption and metabolism via multiple mechanisms. Consequently, the plasma concentrations of drugs are affected, adverse drug reactions are induced, and the therapeutic effects of the drugs are altered. Caffeine, tea polyphenol and daidzein, which are the main active ingredients of coffee, tea and beans, respectively, were utilized in this study to clarify their influences on the in vivo pharmacokinetics of lansoprazole and its major metabolites, 5-hydroxylansoprazole and lansoprazole sulfone, in rats.

\section{MATERIAL AND METHODS}

\section{Material}

Lansoprazole standard (National Institutes for Food and Drug Control, batch No.: 100709-200501), 5-hydroxylansoprazole and lansoprazole sulfone standard (TLC Pharmachem Inc., batch No.: 1020-097A2), lansoprazole raw material (Jiangsu Aokang Group., Ltd., batch No.:F100502), Omeprazole (National Institutes for Food and Drug Control, batch No.: 20050509), caffeine (Beijing Yixiruisi Technology Ltd.), tea polyphenol (Anhui Province Tea Leaves Alkaloid Ltd., batch No.: 080726), daidzein (Zhengzhou Biology Technology Ltd.), methanoic acid and ammonium acetate (analytically pure), acetonitrile (HPLC pure) and double distilled water.

\section{Animal treatment}

Male SD rats (7 weeks, $200 \pm 20 \mathrm{~g}$ ) were obtained from the Experimental Animal Center of Tongji Medical College of Huazhong, University of Science and Technology, China, and housed under controlled conditions. They were maintained on a 12:12 h light-dark cycle at a room temperature of $21^{\circ} \mathrm{C}$. Food and water were available ad libitum. All procedures were consistent with the National Institutes of Health guidelines for the care and use of laboratory animals. The protocol was approved by the Ethical Committee on Animal Experimentation of Tongji Medical College, Huazhong University of Science and Technology, China.

\section{Pharmacokinetics study}

Rats were randomly divided into 4 groups. Four groups of six rats each were separately fed caffeine (30 $\mathrm{mg} \mathrm{kg}^{-1}$, dissolved in $0.5 \%$ carboxymethyl cellulose sodium aqueous solution, once per day), tea polyphenol (400 $\mathrm{mg} \cdot \mathrm{kg}^{-1}$, dissolved in double distilled water, once per day), daidzein (13.5 $\mathrm{mg} \cdot \mathrm{kg}^{-1}$, suspended in $0.5 \%$ carboxymethyl cellulose sodium aqueous solution, once per day) or physiologic saline ( $1 \mathrm{~mL} / 100 \mathrm{~g}$, once per day) for 14 consecutive days. One day after the last treatment, all rats were given lansoprazole $\left(8 \mathrm{mg} \cdot \mathrm{kg}^{-1}\right)$ by gavage. Blood samples $(0.3 \mathrm{~mL})$ were taken from the jugular vein cannula with a heparinized syringe for the determination of the plasma concentration before and $0.08,0.17,0.25,0.33$, $0.5,0.75,1,1.5,2,3,4,5,6 \mathrm{~h}$ after the administration. After the collection of each blood sample, an equal volume of heparinized $0.9 \% \mathrm{NaCl}(20 \mathrm{U} / \mathrm{mL})$ was administered to the animal. The samples were centrifuged at $3000 \mathrm{~g}$ for $10 \mathrm{~min}$ 
at $4{ }^{\circ} \mathrm{C}$ immediately after collection and stored at $-80{ }^{\circ} \mathrm{C}$ until analysis.

\section{HPLC-MS/MS assay of lansoprazole and its metabolites}

The plasma samples were treated with acetonitrile precipitation and omeprazole was used as the internal standard. A Diamonsil $\mathrm{C}_{18}$ column $(5 \mu \mathrm{m}, 150 \times 2.1 \mathrm{~mm})$ was used as the analytical column, with acetonitrile- $0.1 \%(\mathrm{v} / \mathrm{v})$ formic acid and $2 \mathrm{mmol} \cdot \mathrm{L}^{-1}$ ammonium acetate $(43: 57, \mathrm{v} / \mathrm{v})$ as the mobile phase at s flow rate of $0.3 \mathrm{~mL} / \mathrm{min}$. The samples were ionized by electrospray ionization in a triple quadruple tandem mass spectrometer, and the plasma lansoprazole, 5-hydroxylansoprazole, lansoprazole sulfone and internal standard were determined with a multiple reactionmonitoring mode of $\mathrm{m} / \mathrm{z} 368.0 \rightarrow 163.9, \mathrm{~m} / \mathrm{z} 384.1 \rightarrow 179.9$, $\mathrm{m} / \mathrm{z} 383.9 \rightarrow 115.9$ and $\mathrm{m} / \mathrm{z} 326.0 \rightarrow 280.1$, respectively. The linearity was confirmed in the concentration range of 116.00 $46400.00 \mathrm{ng} / \mathrm{mL}, 12.60-5040.00$ and $12.40-4960.00 \mathrm{ng} / \mathrm{mL}$ for lansoprazole, 5-hydroxylansoprazole, and lansoprazole sulfone in rat plasma. The inter-assay and intra-assay CVs of the analysis of the low, medium and high concentration samples for lansoprazole, 5-hydroxylansoprazole and lansoprazole sulfone were all less than $10 \%$. The recovery was determined for six replicates of rat plasma with low, medium and high concentrations of the three analytes $(232.00,6200.00,37120.00 \mathrm{ng} / \mathrm{mL}$ for lansoprazole, 25.20 , $670.00,4032.00 \mathrm{ng} / \mathrm{mL}$ for 5-hydroxylansoprazole, and $24.80,660.00,3968.00 \mathrm{ng} / \mathrm{mL}$ for lansoprazole sulfone). The mean absolute extraction recovery of lansoprazole was $91.44 \pm 4.10 \%, 96.36 \pm 8.62 \%$ and $92.70 \pm 4.93 \%$; the mean absolute recovery of 5-hydroxylansoprazole was $91.25 \pm 8.60 \%, 92.68 \pm 8.55 \%$ and $89.60 \pm 8.33 \%$; and the mean absolute recovery of lansoprazole sulfone was $92.14 \pm 5.30 \%, 91.85 \pm 3.22 \%$ and $93.31 \pm 4.60 \%$. The variability and recovery rates were suitable for pharmacokinetic analysis.

\section{Statistical analysis}

Pharmacokinetic parameters were calculated using the DAS software (Version 2.0, Sun Ruiyuan, China). The data were evaluated using the SPSS 13.0 software for an analysis of variance (ANOVA) followed by a Duncan's multiple comparison test, and $P$ values of less than 0.05 were considered statistically significant.

\section{RESULTS AND DISCUSSION}

\section{Quantitative basis}

The concentration of lansoprazole and its metabolites (5-hydroxylansoprazole and lansoprazole sulfone) in rat plasma was determined by a HPLC-MS/MS method described in detail in our previous work (Liu, Xiang, Ren, 2011). The HPLC-MS/MS method showed satisfactory results for the simultaneous determination of lansoprazole and its metabolites in rat plasma and was successfully used for the investigation of the pharmacokinetic interaction of lansoprazole with other drugs and chemicals (Xiang et al., 2012).

\section{Lansoprazole pharmacokinetics}

As shown in Figure 1, caffeine barely affected

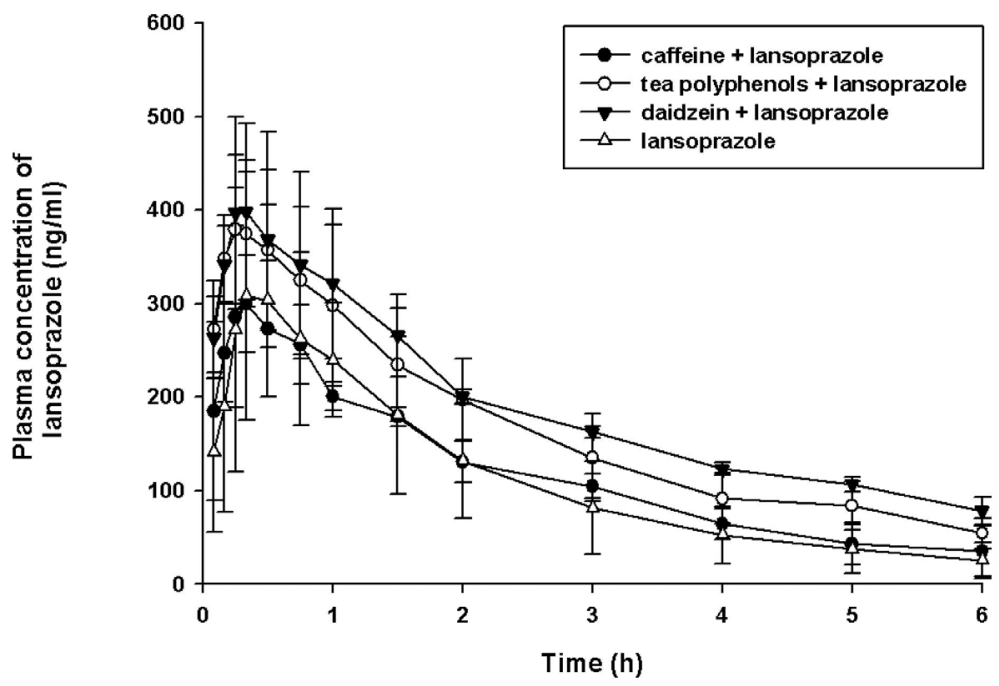

FIGURE 1 - Plasma concentration-time profiles of lansoprazole in rats after a single $8 \mathrm{mg} \cdot \mathrm{kg}^{-1}$ oral dose of lansoprazole in groups with different pretreatments for two weeks. The values shown are the mean \pm S.D. of six rats. 
TABLE I - In vivo pharmacokinetic parameters of lansoprazole in rats $(\overline{\mathrm{x}} \pm$ S.D., $\mathrm{n}=6)$

\begin{tabular}{lcccc}
\hline Parameters & Control group & Caffeine & Tea polyphenol & Daidzein \\
\hline AUC $(\mu \mathrm{g} / \mathrm{L} . \mathrm{h})$ & $680.29 \pm 285.99$ & $710.27 \pm 77.39$ & $949.76 \pm 155.18^{*}$ & $1130.44 \pm 97.69^{*}$ \\
$\mathrm{MRT}(\mathrm{h})$ & $1.76 \pm 0.22$ & $1.95 \pm 0.26$ & $1.92 \pm 0.20$ & $2.22 \pm 0.14^{*}$ \\
$\mathrm{~T}_{1 / 2}(\mathrm{~h})$ & $1.94 \pm 0.85$ & $2.17 \pm 1.33$ & $3.54 \pm 1.80^{*}$ & $3.327 \pm 0.53^{*}$ \\
$\mathrm{~T}_{\max }(\mathrm{h})$ & $0.40 \pm 0.11$ & $0.36 \pm 0.23$ & $0.39 \pm 0.31$ & $0.31 \pm 0.10$ \\
$\mathrm{CL}(\mathrm{L} / \mathrm{h} / \mathrm{kg})$ & $13.54 \pm 9.08$ & $9.75 \pm 2.42$ & $6.24 \pm 1.70$ & $5.18 \pm 0.42^{*}$ \\
$\mathrm{C}_{\max }(\mu \mathrm{g} / \mathrm{L})$ & $328.56 \pm 136.69$ & $323.33 \pm 52.59$ & $403.17 \pm 55.34$ & $427.00 \pm 82.73$ \\
\hline
\end{tabular}

" $p<0.05$ compared with the control group.

the plasma concentration of lansoprazole, but both tea polyphenol and daidzein, particularly the latter, increased the concentration. Table I shows the pharmacokinetic parameters of lansoprazole. The caffeine group was not significantly different from the control group. The AUC of lansoprazole in the rats administered tea polyphenol was 1.4 times higher than that of the control group $(p<0.05)$, and the $\mathrm{T}_{1 / 2}$ of lansoprazole was also prolonged $(p<0.05)$. Daidzein remarkably elevated the AUC of lansoprazole (1.7 times), extended MRT and $\mathrm{T}_{1 / 2}$, and decelerated the clearance $(p<0.05)$.

\section{5-Hydroxylansoprazole pharmacokinetics}

The curves plotting the plasma concentrations of 5-hydroxylansoprazole in each group versus time are shown in Figure 2. The plasma concentrations of all groups did not obviously differ. The pharmacokinetic parameters of 5-hydroxylansoprazole are shown in Table II. Tea polyphenol, daidzein and caffeine did not influence the pharmacokinetic parameters of 5-hydroxylansoprazole.

\section{Lansoprazole sulfone pharmacokinetics}

The dependences of the plasma concentrations of lansoprazole sulfone on time are plotted in Figure 3, indicating that tea polyphenol and daidzein, especially the latter, dramatically lowered the plasma concentration of lansoprazole sulfone. The pharmacokinetic parameters of lansoprazole sulfone are shown in Table III. Caffeine did not exert discernible effects on the pharmacokinetic parameters of lansoprazole sulfone. However, tea polyphenol significantly reduced the AUC of lansoprazole sulfone by $66 \%$ and $\mathrm{C}_{\max }$, and slowed down its clearance in vivo $(p<0.05)$. The AUC of lansoprazole sulfone in the rats administered daidzein was markedly lowered, by $43 \%$, compared to the control group, and the $\mathrm{C}_{\max }$ was also obviously decreased compared with the control group $(p<0.05)$.

The simultaneous intake of food and drugs is a ubiquitous protocol. The influences of food such as grapefruit juice and Carica papaya extract on drug pharmacokinetics have frequently been addressed

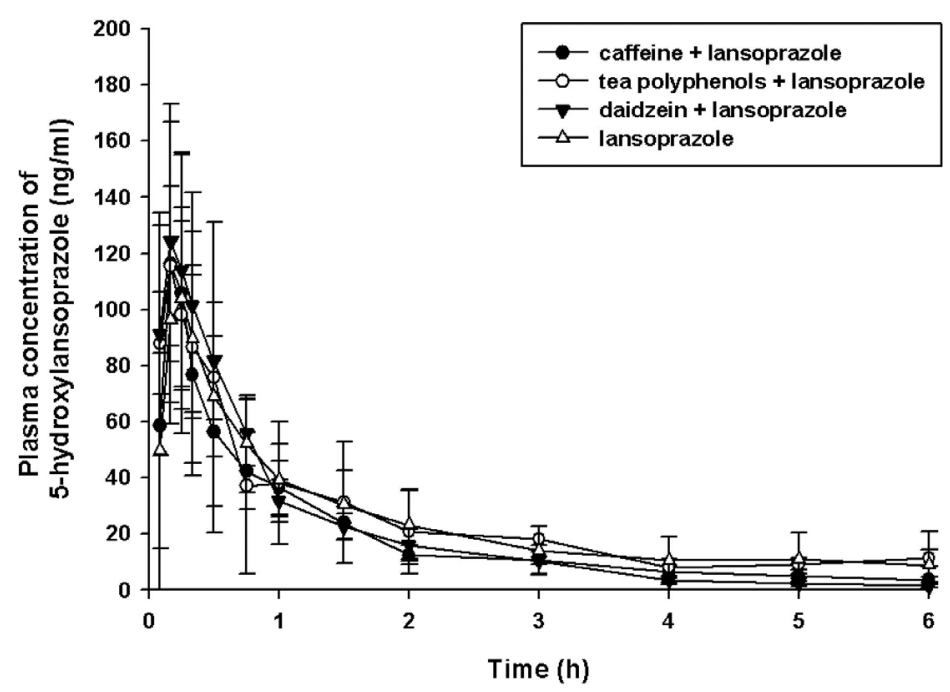

FIGURE 2 - Plasma concentration-time profiles of 5-hydroxylansoprazole in rats after a single $8 \mathrm{mg} \cdot \mathrm{kg}^{-1} \mathrm{oral} \mathrm{dose} \mathrm{of} \mathrm{lansoprazole}$ in groups with different pretreatments for two weeks. The values shown are the mean \pm S.D. of six rats. 
TABLE II - In vivo pharmacokinetic parameters of 5-hydroxylansoprazole in rats ( $\overline{\mathrm{x}} \pm$ S.D., $\mathrm{n}=6)$

\begin{tabular}{lcccc}
\hline Parameters & Control group & Caffeine & Tea polyphenol & Daidzein \\
\hline AUC $(\mu \mathrm{g} / \mathrm{L} . \mathrm{h})$ & $140.76 \pm 62.62$ & $108.23 \pm 31.76$ & $109.12 \pm 68.98$ & $116.73 \pm 31.64$ \\
$\mathrm{MRT}(\mathrm{h})$ & $1.52 \pm 0.38$ & $1.30 \pm 0.46$ & $1.11 \pm 0.73$ & $1.02 \pm 0.18$ \\
$\mathrm{~T}_{1 / 2}(\mathrm{~h})$ & $2.10 \pm 1.36$ & $2.24 \pm 1.22$ & $1.37 \pm 1.51$ & $1.42 \pm 0.59$ \\
$\mathrm{~T}_{\max }(\mathrm{h})$ & $0.22 \pm 0.04$ & $0.22 \pm 0.07$ & $0.22 \pm 0.15$ & $0.22 \pm 0.09$ \\
$\mathrm{CL}(\mathrm{L} / \mathrm{h} / \mathrm{kg})$ & $60.33 \pm 31.89$ & $70.87 \pm 21.69$ & $91.63 \pm 70.41$ & $66.95 \pm 18.85$ \\
$\mathrm{C}_{\max }(\mu \mathrm{g} / \mathrm{L})$ & $106.83 \pm 28.53$ & $136.43 \pm 53.91$ & $132.50 \pm 36.47$ & $127.83 \pm 37.14$ \\
\hline
\end{tabular}

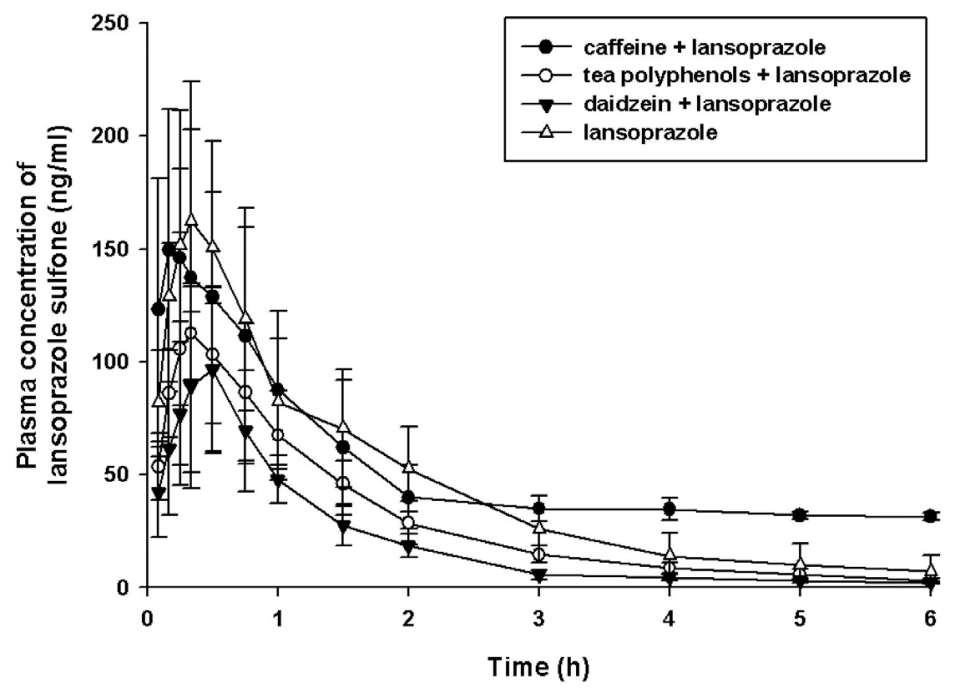

FIGURE 3 - Plasma concentration-time profiles of lansoprazole sulfone in rats after a single $8 \mathrm{mg} \cdot \mathrm{kg}^{-1}$ oral dose of lansoprazole in groups with different pretreatments for two weeks. The values shown are the mean \pm S.D. of six rats.

TABLE III - In vivo pharmacokinetic parameters of lansoprazole sulfone in rats $(\overline{\mathrm{x}} \pm$ S.D., $\mathrm{n}=6)$

\begin{tabular}{lcccc}
\hline Parameters & Control group & Caffeine & Tea polyphenol & Daidzein \\
\hline AUC $(\mu \mathrm{g} / \mathrm{L} . \mathrm{h})$ & $268.82 \pm 82.37$ & $240.16 \pm 124.42$ & $177.72 \pm 29.73^{*}$ & $116.23 \pm 40.14^{*}$ \\
$\mathrm{MRT}(\mathrm{h})$ & $1.42 \pm 0.29$ & $1.35 \pm 0.66$ & $1.43 \pm 0.18$ & $1.05 \pm 0.22$ \\
$\mathrm{~T}_{1 / 2}(\mathrm{~h})$ & $1.47 \pm 0.57$ & $12.46 \pm 18.42$ & $1.18 \pm 0.13$ & $1.50 \pm 1.26$ \\
$\mathrm{~T}_{\max }(\mathrm{h})$ & $0.40 \pm 0.20$ & $0.23 \pm 0.06$ & $0.29 \pm 0.11$ & $0.40 \pm 0.11$ \\
$\mathrm{CL}(\mathrm{L} / \mathrm{h} / \mathrm{kg})$ & $31.24 \pm 12.07$ & $28.68 \pm 21.44$ & $44.76 \pm 6.76^{*}$ & $69.04 \pm 20.96^{*}$ \\
$\mathrm{C}_{\max }(\mu \mathrm{g} / \mathrm{L})$ & $170.08 \pm 31.51$ & $166.23 \pm 79.28$ & $128.68 \pm 28.98^{*}$ & $103.85 \pm 39.20^{*}$ \\
\hline
\end{tabular}

${ }^{*} p<0.05$ compared with the control group.

(Rodrigues et al., 2014; Boddu et al., 2009). Cytochrome P450 enzymes are most closely associated with drug metabolism, including CYP3A as the most critical ingredient and $\mathrm{CYP} 2 \mathrm{C}$ as a huge subfamily. Lansoprazole is primarily metabolized by CYP3A and CYP2C19, alterations of which may influence the effects of proton pump inhibitors. In this study, we attempted to explore the effects of the common dietary factors caffeine, tea polyphenol and daidzein on the in vivo pharmacokinetics of lansoprazole and its metabolites in rats.
Caffeine, which is widely distributed in food and beverages, is metabolized almost completely by the liver. The metabolism of caffeine that involves the competition between many enzymes enables it to determine CYP1A2 effectively as a probe drug (Hakooz, 2009). Regardless, the impact of caffeine on proton pump inhibitors or CYP2C19 and CYP3A has not been reported previously. The results herein suggested that caffeine had no effect on lansoprazole and its two main metabolites.

Tea is habitually drunk in Asia and the UK. Tea 
polyphenol, as the main biologically active ingredient in tea, accounts for $20-30 \%$ of the dry weight. Moreover, tea polyphenol has extensively been used in food manufacturing as an additive because it is a potent antioxidant. In recent years, the influence of tea polyphenol on enzyme metabolism has been studied. Engdal and Nilsen found that green tea inhibited (IC50: $73 \mu \mathrm{g} / \mathrm{mL}$ ) the in vitro metabolism of CYP3A4 that was expressed from c-DNA baculovirus utilizing testosterone as the substrate (Engdal, Nilsen, 2009). This study found that tea polyphenol significantly increased the AUC of lansoprazole, indicating that tea polyphenol suppressed the in vivo metabolism of lansoprazole. Meanwhile, the detection of metabolites revealed that tea polyphenol did not affect the metabolic product 5-hydroxylansoprazole mediated by CYP2C19, whereas it remarkably reduced the AUC and $\mathrm{C}_{\max }$ of lansoprazole sulfone metabolized by CYP3A. These results suggest that tea polyphenol may inhibit the CYP3A activity in vivo, thereby elevating the plasma concentration of lansoprazole.

Soy products, such as soy milk, tofu and soy sauce, are widely available in daily life. The consumption of fermented soybean products is gradually increasing around the world, due to their various health benefits (Kim et al., 2010). Genistein, flavones and isoflavones in soy can inhibit the activity of CYP3A4 (Scott et al., 2008). High-content daidzein, which is a soy isoflavone, has been detected in celery and arrowroot. In addition, daidzein is pharmacologically capable of treating coronary heart disease, hypertension and hyperlipidemia, resisting tumors and preventing osteoporosis. Thus, daidzein has been clinically applied. Foster et al. reported that daidzein inhibited the in vitro activity of human liver microsomal enzyme CYP3A4 (Foster et al., 2003). In this study, daidzein increased the AUC of lansoprazole and reduced the AUC of lansoprazole sulfone but maintained the pharmacokinetics of 5-hydroxylansoprazole. The results reveal that daidzein may inhibit the in vivo metabolism of lansoprazole by suppressing the activity of CYP3A.

Detecting the plasma concentrations of lansoprazole and its two main metabolites in rats by mass spectrometry demonstrated that tea polyphenol and daidzein probably suppressed the metabolism of lansoprazole by inhibiting CYP3A activity, while caffeine barely influenced the pharmacokinetic parameters of lansoprazole. This study provides a reference for future dietary recommendations in the case of clinically used proton pump inhibitors. This report is on the rat CYP-related interaction; a human CYP transgenic animal study is ongoing.

\section{CONCLUSIONS}

Tea polyphenol and daidzein may inhibit the in vivo metabolism of lansoprazole by suppressing the activity of CYP3A, thereby raising the plasma concentration of lansoprazole.

\section{REFERENCES}

BODDU, S.P.; YAMSANI, M.R.; POTHARAJU, S.; VEERARAGHAVAN, S.; RAJAK, S.; KUMA, S.V.; AVERY, B.A.; REPKA, M.A.; VARANASI, V.S. Influence of grapefruit juice on the pharmacokinetics of diltiazem in Wistar rats upon single and multiple dosage regimens. Pharmazie, v.64, p.525-531, 2009.

BRITTO, M.R.; MCKEAN, H.E.; BRUCKNER, G.G.; WEDLUND, P.J. Polymorphisms in oxidative drug metabolism: relationship to food preference. Br. J. Clin. Pharmac., v.32, p.235-237, 1991.

ENGDAL, S.; NILSEN, O.G. In vitro inhibition of CYP3A4 by herbal remedies frequently used by cancer patients. Phytother. Res., v.23, p.906-912, 2009.

FOSTER, B.C.; VANDENHOEK, S.; HANA, J.; KRANTIS, A.; AKHTAR, M.H.; BRYAN, M.; BUDZINSKI, J.W.; RAMPUTH, A.; ARNASON, J.T. In vitro inhibition of human cytochrome P450-mediated metabolism of marker substrates by natural products. Phytomedicine, v.10, p.334342, 2003.

HAKOOZ, N.M. Caffeine metabolic ratios for the in vivo evaluation of CYP1A2, N-acetyltransferase 2, xanthine oxidase and CYP2A6 enzymatic activities. Curr. Drug Metab., v.10, p.329-338, 2009.

INOUE, M.; OKADA, H.; HORI, S.; KAWAHARA, Y.; KAWANO, S.; TAKENAKA, R.; TOYOKAWA, T.; ONISHI, Y.; SHIRATORI, Y.; YAMAMOTO, K. Does pretreatment with lansoprazole influence Helicobacter pylori eradication rate and quality of life? Digestion, v.81, p.218-222, 2010.

KIM, H.G.; HONG, J.H.; SONG, C.K.; SHIN, H.W.; KIM, K.O. Sensory characteristics and consumer acceptability of fermented soybean paste (Doenjang). J. Food Sci., v.75, p.S375-S383, 2010. 
LIU, D.; XIANG, D.; REN, X. Determination of Lansoprazole and its metabolites in rat plasma by HPLC-MS/MS. China Pharmacist, v.14, p.176-179, 2011.

NOWACK, R. Review article: cytochrome P450 enzyme, and transport protein mediated herb-drug interactions in renal transplant patients: grapefruit juice, St John's Wort - and beyond! Nephrology, v.13, p.337-347, 2008.

RODRIGUES, M.; ALVES, G.; FRANCISCO, J.; FORTUNA, A.; FALCÃO, A. Herb-drug Pharmacokinetic Interaction between Carica Papaya Extract and Amiodarone in Rats. J. Pharm. Pharm. Sci., v.17, p.302-315, 2014.

SAITO, M.; YASUI-FURUKORI, N.; UNO, T.; TAKAHATA, T.; SUGAWARA, K.; MUNAKATA, A.; TATEISHI, T. Effects of clarithromycin on lansoprazole pharmacokinetics between CYP2C19 genotypes. Br. J. Clin. Pharmacol., v.59, p.302-309, 2005.
SCOTT, L.M.; DURANT, P.; LEONE-KABLER, S.; WOOD, C.E.; REGISTER, T.C.; TOWNSEND, A.; CLINE, J.M. Effects of prior oral contraceptive use and soy isoflavonoids on estrogen-metabolizing cytochrome P450 enzymes. $J$. Steroid Biochem. Mol. Biol., v.112, p.179-185, 2008.

SPENCER, C.M.; FAULDS, D. Lansoprazole: a reappraisal of its pharmacodynamic and pharmacokinetic properties, and its therapeutic efficacy in acid-related disorders. Drugs, v.48, p.404-430, 1994.

XIANG, D.; XU, Y.; REN, X.; LIU, D. Effect of furazolidone on the pharmacokinetics of lansoprazole and its metabolites in rats. Chinese Pharm. J., v.47, p.458-461, 2012.

ZHANG, D.; YANG, M.; LIU, M.; ZHANG, Y.; WANG, X.; XIAO, X.; LIU, H. Pharmacokinetics of lansoprazole and its main metabolites after single intravenous doses in healthy Chinese subjects. Xenobiotica, v.11, p.1156-1162, 2012.

Received for publication on $05^{\text {th }}$ November 2014 Accepted for publication on $28^{\text {th }}$ July 2015 
